\title{
O ANONIMATO ESPACIAL COMO UM IMPASSE METODOLÓGICO NA PESQUISA GEOGRÁFICA E UMA REFLEXÃO ONTOLÓGICA
}

\author{
Daniel Abreu Azevedo \\ Universidade Federal do Rio de Janeiro - UFRJ \\ Pós-doutorando em Geografia Social na Universidad Nacional Autónoma de México \\ dan abreudeazevedo@hotmail.com
}

\begin{abstract}
RESUMO
Esse artigo tem como objetivo central analisar como um problema metodológico no trabalho de campo em uma tese de doutoramento revelou questões ontológicas da própria ciência geográfica. Para tanto, será importante voltar alguns dos principais trabalhos geográficos para revelar como a tríade localização-descriçãorepresentação é o verdadeiro espírito geográfico que atravessa todas as correntes da Geografia. Durante dois anos de trabalhos de campo para uma tese de doutorado, a impossibilidade de revelar a identidade de atores políticos levou também à necessidade de não identificar os espaços geográficos envolvidos na pesquisa. Sem ser um grande problema metodológico em diferentes ciências humanas, essa dificuldade para o geógrafo reflete, acima de tudo, as inquietações da geografia como ciência.
\end{abstract}

Palavras-chave: Localização. Descrição. Representação. Trabalho de campo. Pesquisa qualitativa.

\section{SPACE ANONIMATE AS A METHODOLOGICAL ISSUE IN GEOGRAPHICAL RESEARCH AND AN ONTOLOGICAL REVIEW}

\begin{abstract}
This article aims to analyze how a methodological problem in a phD thesis field work reveals ontological questions of geographic science itself. To do so, it will be important to interpretate some of the major geographic works to reveal how the triad location-description-representation is the true geographic spirit that crosses all the currents of Geography. During two years of fieldwork for a phD thesis, the impossibility of revealing the identity of political actors also led to not identify the geographical spaces involved in the research. Without being a major methodological problem in different human sciences, this problem for geographers reflects, above all, the concerns of geography as a science.
\end{abstract}

Keywords: Location. Description. Representation. Fieldwork. Qualitative research.

\section{INTRODUÇÃO}

No decorrer de qualquer pesquisa, seja usando métodos quantitativos, seja usando métodos qualitativos, inúmeros desafios podem surgir que colocam o pesquisador em uma complicada posição. Problemas oriundos de um financiamento escasso, falta de tempo ou de ordem metodológica geralmente se apresentam no decorrer de uma tese e precisam ser resolvidas para realizar uma boa investigação. Em o famoso livro Como se faz uma tese (2008), Umberto Eco apresentou distintas dificuldades que se impõem a um pesquisador e, com um tom muitas vezes sarcástico, apontou até mesmo para armadilhas que cai um pesquisador e podem colocar em risco toda a sua tese.

Nesse sentido, esse artigo tem como objetivo central analisar um desafio metodológico surgido na produção de tese de doutoramento e como, ao final, as questões levantadas nos levaram a pensar a própria ontologia da geografia. Durante dois anos de trabalhos de campo, foi necessário estar presente em duas favelas no Rio de Janeiro, para compreender as dinâmicas sócio-políticas de suas Associações de Moradores. Ao longo desse período, os dois 
presidentes dessas instituições se tornaram valiosos informantes na pesquisa, contando, inclusive, com inesperada abertura para assuntos delicados. Entretanto, o pedido para não serem identificados e também terem uma cópia do trabalho final gerou uma crucial questão metodológica: a impossibilidade de identificação de seus nomes tornava, consequentemente, impossível georreferenciar a pesquisa, visto que a simples localização da favela, daria o nome do líder que era preciso ocultar. A ética na pesquisa qualitativa (SMITH, 2010) gerou um interessante problema de investigação, pois o anonimato das pessoas se tornou um anonimato espacial.

A completa ausência de soluções metodológicas para esse problema na literatura e também um exame de qualificação com reconhecidos geógrafos que resultou em uma não solução para a questão, impuseram um desafio a mais na produção da tese: como produzir um trabalho em geografia sem usar da tríade localização-descrição-representação?

Nota-se que em outras ciências humanas que utilizam o trabalho de campo como principal método de investigação, a ocultação dos nomes de personagens parece uma prática mais trivial. Na antropologia e suas etnografias é muito comum não mencionar nenhum nome verdadeiro, criando codinomes que apenas o investigador saberia traduzir. $\mathrm{O}$ trabalho de Don Kulick sobre travestis em Salvador (KULICK, 1998) é um interessante exemplo. Na sociologia, também é comum a omissão de nomes e a tentativa de criar um cenário-modelo com atores sem seus verdadeiros nomes, como é possível perceber no clássico Sociedades de Esquina (2005 [1951]), de William Foote Whyte. Ao longo dos dois anos de trabalhos de campo, tornouse notório que a tarefa de subtrair nomes e localizações não era algo trivial para uma pesquisa em geografia. Essa inquietação conduziu todo o doutoramento e impôs questões, como: de que modo essa dificuldade metodológica expõe as especificidades da ciência geográfica? De que modo essa barreira pode ser superada, se precisa ser? Seria essa barreira intransponível inviabilizando algumas pesquisas de campo em geografia? Como ficam os tradicionais métodos da pesquisa geográfica, como a observação e a descrição, no meio desse problema? E seu principal modo de representação espacial, o mapa? Se existe uma impossibilidade de indicar coordenadas geográficas e, assim, cartografar o espaço, como produzir uma pesquisa em geografia sem seu principal recurso analítico?

Essas questões são importantes porque derivam da percepção que a geografia tem suas particularidades e seus problemas metodológicos não se resumem às demais ciências humanas. Estas, por sua vez, possuem outras dificuldades; é importante, portanto, identificar quais são as nossas. Nesse sentido, esse artigo está dividido em três partes, além dessa introdução. Em primeiro momento, o trabalho de campo realizado nos anos de 2015-2016 será apresentado, sublinhando os momentos decisivos nos quais o impasse surgiu. Em seguida, diferentes autores e períodos históricos da ciência geográfica serão trazidos para demonstrar que o espírito geográfico se faz presente na tríade localização-descrição-representação. Interessante notar que, apesar da grande diversidade epistemológica da Geografia, esses três elementos sempre aparecem como importantes em uma análise espacial, diferenciando-se em status e objetivos. Assim, na última seção, como tentativa de conclusão, a solução encontrada na pesquisa de doutoramento será apresentada como uma tentativa, ainda que ineficaz para lidar com o dilema enfrentado. O problema trazido pelo trabalho de campo e a bagagem conceitual-metodológica da geografia revelam que longe de ser uma simples questão de operacionalização de pesquisa, a dificuldade em encontrar solução para esse problema se encontra no próprio cerne da geografia como ciência.

\section{METODOLOGIA}

A tese de doutoramento analisou o modelo da democracia participativa a partir de uma perspectiva geográfica. Para compreender os limites e as virtudes desse suposto novo modelo, algumas instituições conhecidas dentro da democracia representativa foram trazidas e comparadas com as novas criadas, utilizando os conceitos de espaço político e de escala política para revelar a espacialidade da democracia. A defesa da tese intitulada $A$ democracia participativa como um sofisma: uma interpretação geográfica da democracia foi realizada e aprovada no Departamento de Geografia da Universidade Federal do Rio de Janeiro no final de outubro de 2016.

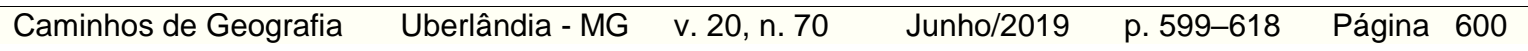


As Associações de Moradores (AMs) foram selecionadas porque representam um tipo de associação tradicional dentro da democracia representativa. Antes mesmo da consolidação do debate sobre democracia participativa no Brasil após 1988, e até mesmo antes da ditadura militar, elas já existiam no país, apesar de ganharem força principalmente na década de 1990 (SOARES, 1989; AVRITZER, 1997). Elas simbolizam um grande exemplo da necessidade de relação entre as escalas políticas mais tradicionais e associações locais para o funcionamento da democracia representativa. Revelam, portanto, a capacidade de associação da sociedade local e a democracia representativa.

Três associações de moradores foram selecionadas e, em comparação com as instituições criadas com o suposto novo modelo da democracia participativa (os Conselhos Municipais), o objetivo foi lançar luz para seu caráter de espaço político dentro da democracia representativa. Essas escolhas respeitaram uma característica do Rio de Janeiro: as AMs representam realidades sócio-espaciais muito distintas, que variam desde bairros de classe social alta, até favelas com domínio territorial do tráfico de drogas. Esse modo de seleção pode ser denominado não probabilístico de amostragem por tipicidade ou intencional (GIL, 1999), isto é, os três casos não foram escolhidos por meio de uma análise matemática complexa de todos os casos possíveis, tendo sido feita uma seleção que possa ser considerada representativa da maioria dos casos do universo retratado.

Os três casos tentam abarcar essas diferenças, ao ter sido selecionada:

I. Uma associação de moradores representante de uma realidade social de uma favela, mas, apesar de um alto grau de pobreza, não existir o conflito territorial do Estado contra grupos de narcotraficantes;

II. Uma associação de moradores representante de uma realidade social de uma favela dominada por facção criminosa;

III. Uma associação de moradores representante de uma realidade de classe média/classe média alta carioca e sem domínio espacial de poderes paralelos ao Estado.

A escolha das três específicas Associações seguiu a a metodologia de observação discutida por Spradley (1980). O autor descreveu um caminho que começaria da observação descritiva à observação seletiva, passando pela observação focada. A primeira seria realizada ainda na fase inicial da pesquisa, para colher informações, dados e caracterizações gerais do objeto em estudo. Assim, no período de observação descritiva, outras cinco associações foram visitadas. Além do bairro de Botafogo, duas que atenderiam ao tipo III, as de São Conrado e do Leblon. O mesmo ocorreu para os casos 1 e 2 . As três foram selecionadas para a fase da observação focada e a observação seletiva devido à maior abertura para a pesquisa com o líder (no caso I), em razão da segurança necessária para a realização do trabalho (no caso II) e uma frequência maior de reuniões abertas (no caso III). Por não existirem reuniões abertas para acompanhamento nos casos I e II para a observação não-participante, foi necessário um "trabalho de campo participante" (SOUZA, 2013) no qual a produção dos dados é realizada através do contato com "a realidade concreta da vida cotidiana dos próprios participantes individuais ou coletivos do processo, em suas diferentes dimensões e interações" (SOUZA, 2013, p.58).

Com a Associação do tipo I foram, ao total, quinze dias de acompanhamentos que começavam pela manhã e terminavam ao final da tarde. Ao longo das minhas horas diárias com 0 presidente da Associação, pude percorrer toda a favela ao seu lado e trabalhar em algumas tarefas solicitadas por ele. Já na Associação do tipo II, devido à atuação do narcotráfico e uma tensão sempre latente, apenas dez dias de acompanhamentos foram possíveis. Destaca-se que para as Associações do tipo I e II, todas as informações foram colhidas por meio de trabalho de campo participante e entrevistas não-estruturadas, pois não havia atas, sites ou reuniões periódicas nos quais outros tipos de metodologias qualitativas pudessem ser utilizados. O registro das entrevistas foi feito por meio de caderno de notas posteriormente ao encontro para as AMs do tipo I e II, e gravador digital para o tipo III. A partir de contatos pessoais denominado como snowball technique (SECOR, 2010), foi possível chegar às favelas e tecer contato com seus líderes. 
Essas diferenças de abordagem entre as três AMs são reflexos de seus complexos contextos sócio espaciais. Era impossível, portanto, observar, descrever e mapear do mesmo modo os três supostos espaços políticos selecionados. Para não fugir do objetivo central desse artigo, apenas as duas primeiras Associações de Moradores trabalhadas serão apresentadas, pois, a dificuldade metodológica surgiu em seus respectivos trabalhos de campo.

Com o objetivo de apresentar a dificuldade metodológica como uma questão ontológica da Geografia, parte-se de revisão bibliográfica de literatura tradicional no campo geográfico para revelar de que modo a dificuldade encontrada faz parte do que se considera como o espírito geográfico por excelência. Diferentes momentos da epistemologia da geografia foram visitados e a tríade localização-descrição-apresentação foi analisada a partir de seus principais clássicos.

\section{RESULTADOS E DISCUSSÃO}

\section{O TRABALHO DE CAMPO E AS INQUIETAÇÕES METODOLÓGICAS}

De modo surpreendente, já no segundo dia de convivência, os líderes das AMs se mostraram abertos a conversar sobre temas complicados. Foi possível acompanhá-los em conversas formais e informais com moradores locais, em reuniões com órgãos do governo, políticos já eleitos e candidatos, além de percorrer a pé todo o território das favelas acompanhado por eles. Essa inesperada facilidade de convivência com os líderes pode ser atribuída ao modo pelo qual o trabalho de campo começou, isto é, a partir de uma indicação de uma pessoa de confiança em comum. Entretanto, mesmo assim, os dois líderes pediram que seus nomes fossem ocultados e que uma cópia do trabalho fosse entregue ao final de sua produção. Surgiu, portanto, um grande desafio metodológico como geógrafo.

A substituição de nomes verdadeiros por codinomes não é um problema quando se analisa um grande universo amostral, no qual os informantes não possuem nomes conhecidos publicamente. Nesses casos, os anonimatos não seriam quebrados quando o espaço trabalhado fosse cartografado, pois, não haveria associação direta entre as pessoas e o espaço. Não haveria, portanto, dificuldade se a omissão dos nomes fosse de moradores comuns das favelas. Esse não é o caso do trabalho de campo nas Associações de Moradores. Qualquer identificação espacial colocaria em risco o anonimato dos informantes, pois bastaria uma busca rápida na internet para ligar às $\mathrm{AMs}$ com seus líderes. $\mathrm{O}$ anonimato das pessoas se transformou, pois, em um anonimato espacial.

$\mathrm{Na}$ Associação de Moradores do tipo 1 (doravante denominada ASSI) a pesquisa revelou um líder com traços patrimonialista, populista e personalista, como definido por Nunes (2010). Ele é a ponte entre a comunidade e o Estado, o modo pelo qual as demandas da comunidade chegam ao poder público. Devido à baixa capilaridade do Estado na comunidade, o líder comunitário ganha sua força na rede de contatos que ele possui, inclusive dentro da própria Prefeitura. Entretanto, em diferentes situações, ele não vai atrás do Estado; ele incorpora as funções que seriam do próprio Estado, como na construção de uma rua só para pedestres, na emissão de autorização de trabalho a vendedores ou até mesmo incorporando o poder de polícia para manutenção da escorreita ordem na comunidade.

Ao perguntar onde eram as reuniões com os moradores, o líder me informou que raramente ocorriam (a última teria sido três anos antes dessa conversa). Segundo ele, "os moradores não sentem necessidade de ter reuniões. Eles confiam muito em mim". A imbricação entre casa do líder-ASSI-comunidade revelou que os dois últimos funcionam, para o presidente, como extensão da casa. Vestuário, modo de se comportar e falar, a "não necessidade" de reuniões, a falta de espaço para tal e a forma pela qual o presidente age na comunidade estão interligados. O local, incorporado na figura da favela, é a extensão de sua casa; de seu domínio espacial. Ao longo de diversas caminhadas, os moradores utilizavam vocativos como "comandante", "chefe" e "grande" a fim de chamar sua atenção.

Além de possível benefício econômico, o líder da Associação desfrutava de uma posição hierárquica importante dentro da comunidade. Isso se estabelece também por meio de uma baixa rotatividade na presidência da ASSI. Ele me informou que o mandato duraria quatro anos, mas já continuava como presidente mesmo com um atraso de dois anos para a convocação de novas eleições. Segundo o líder, "não tem ninguém que goste de pegar esse

$\begin{array}{llllll}\text { Caminhos de Geografia } & \text { Uberlândia - MG } & \text { v. 20, n. } 70 & \text { Junho/2019 } & \text { p. 599-618 Página } 602\end{array}$


abacaxi". Ele é o mantenedor de uma ordem. Em um forte relato, ele mostrou a arma que utilizou para matar um rapaz menor de idade que estava roubando carros dentro da comunidade. O líder afirmou, cabisbaixo, como não lhe restara outra alternativa para acabar com o "problema": "Me arrependo disso, não faria. Mas, fiz. E passei a ser conhecido como 'destemido' né, porque você sabe, a notícia se espalhou. Depois que o cara roubou o meu carro e fui tirar satisfação com ele, e ele me reconheceu, porque todo mundo falava quem eu era. Aí ele tentou sair correndo. Dei três tiros nas costas dele. Cheguei perto dele caído no chão e como já tinha começado a merda, resolvi terminar: coloquei o cano na boca dele e disparei. Os moradores vinham toda hora me perguntando quando eu ia tomar uma providência em relação ao que estava acontecendo. Não tive opção".

Essa conversa preencheu de sentido uma frase que a vice-presidente tinha respondido em entrevista algumas semanas antes. Ao perguntar se era mais fácil ser da Associação em uma comunidade sem controle de traficantes, ela afirmou que sim, mas complementou que "aqui também tem a UPP Cláudio [nome fictício]" e riu. Ao se referir à política de governo do Estado do Rio de Janeiro implementada desde 2008 em favelas antes dominadas pelo tráfico, a vicepresidente estava relatando sobre a atuação do líder como elemento-chave para garantia das normas.

Em outro dia, paramos para conversar com uma jovem mulher da Secretaria do Meio Ambiente que vai à favela ao menos uma vez por semana para acompanhar o estado (precário) dos rios e vegetações que a circundam. Na conversa dos dois, ele comentou: "Você lembra daquele negão que deixei vender o churrasquinho aqui? Mandei embora!'. Ele fez questão de explicar: "negão de 2 metros que veio chorando porque a Prefeitura tinha proibido ele de vender churrasquinho lá fora da comunidade. Fiquei com pena do cara e permiti ele vender aqui. Mas, aí ele pisou na bola e mandei ele embora. Tratou mal alguns moradores e estava vendendo frango por um preço mais caro que a gente encontra lá fora. Eu pedi para ele juntar as tralhas dele e se mandar daqui. Aqui dentro eu consegui que ele trabalhasse porque a fiscalização é parceira".

O mesmo se repetiu quando falou sobre o sacolão volante. A prefeitura tinha expulsado o caminhão de sacolão e também o vendedor de pastel da entrada da favela. Para resolver o problema, o líder ligou para um conhecido, identificou-se e afirmou trabalhar no gabinete de um vereador. Passados dois dias, a fiscalização teria afrouxado e permitido que as pessoas trabalhassem. No sacolão, ele pegou frutas, comeu e não pagou. O mesmo ocorreu na barraca do pastel. Não foi cobrado. Isso voltaria a ocorrer com um senhor que ele convidou para sua casa para pintar três paredes. Ao perguntar "quanto você faria pra mim?", o senhor respondeu: "tá maluco, chefe? Não quero seu dinheiro não. Faço de graça para você".

Suas redes de contatos favorecem a Comunidade de diferentes modos, desde serviços trazidos aos moradores ou até mesmo em resolução de problemas pessoais. Ao questioná-lo sobre qual seria o papel de um presidente de Associação de Moradores, ele respondeu: "Coloque aí nas suas anotações. O principal papel do Presidente da Associação de Moradores é quebrar dificuldades através dos contatos que ele tem. Melhor presidente quanto mais contato se tem". Afirmou ainda que os contatos que tem já teriam vindo antes de ser presidente e o cargo o ajudou a reforçá-los por meio de uma densa rede de favores. Essa rede de contatos inclui também representantes do Poder Legislativo municipal. A situação empregatícia desse líder era nebulosa, pois, mesmo com recursos oriundos da ASSI, seu padrão de vida (possuía uma moto, carro e uma grande casa que estava sempre em processo de reforma) não era condizente com os valores que a vice-presidente afirmou que ele recebia. Ao longo de conversas mais difíceis de serem estabelecidas, ficou claro que ele possui vínculo com o gabinete de um Vereador, apesar de raramente ir à Câmara dos Vereadores. A relação existente com o representante era tão visível que mesmo em sua página pessoal em redes sociais, constantemente, havia menções ao Vereador.

Como é possível perceber, nos dias de trabalho de campo nessa favela do Rio de Janeiro diferentes temas surgiram e tornaram ainda mais clara a dificuldade que a tese enfrentaria em seu processo de localização, descrição e representação do objeto de estudo. A relação escusa com representantes do Poder Legislativo municipal, a configuração da Associação de Moradores e até mesmo a confissão de um assassinato colocaram em xeque qualquer possibilidade de identificação espacial. Esses elementos não poderiam ser simplesmente apagados da pesquisa, porque ajudavam a caracterizar aquele suposto espaço político e perceber seus limites. 
Diferentemente da primeira, a Associação de Moradores do tipo II (doravante denominada ASSII) representa um território controlado por grupos de narcotraficantes. Algumas ruas antes de chegar de motocicleta à entrada da favela, uma abordagem brusca exigiu que o capacete fosse retirado. Quanto mais próximo à entrada da favela, mais era possível avistar objetos que serviam como escudo e pessoas fortemente armadas, observando quem chegava e quem saía. Nesse ambiente, o líder da associação se apresentou. No primeiro dia, já era possível perceber que haveria fortes diferenças na realização desse trabalho de campo em relação ao anterior. Em dois momentos distintos, ele apontou lugares que não seria possível ir porque teria que dar muita satisfação sobre a presença de uma pessoa estranha. Em um dos dias de pesquisa, no momento em que algumas fotos foram feitas, homens com rádios perguntaram o que estava acontecendo. O presidente da ASSII interviu e disse que era um trabalho sobre poluição dos rios, a Baía de Guanabara e os Jogos Olímpicos que estavam se aproximando.

É neste contexto socioespacial que o papel da ASSII para sua favela foi analisado. Durante anos anteriores a Associação esteve fechada por ordem dos traficantes da área e, por meio de intensas conversas, permitiram que voltasse. Segundo o líder da ASSII, "os donos da favela" percebiam que a comunidade e também eles mesmos perdiam muito com a falta da Associação, pois o Estado, suas empresas de serviços públicos e grupos privados ou do Terceiro Setor de assistência social possuíam muitas dificuldades de estabelecer contato com os moradores da favela. Além disso, o presidente relatou que durante muito tempo os moradores se acostumaram a resolver os problemas diretamente com os traficantes, o que até hoje seria um problema, pois muitos ainda não olhariam para a ASSII como um espaço de resolução de conflitos e continuariam buscando os mesmos personagens ligados ao crime organizado. Ele me relatou, ainda, um problema com um ex-marido que não pagava pensão para o filho. A ex-esposa, moradora também da Comunidade II, o denunciou à Justiça, levando um oficial a levar uma intimação e, pela persistência do não pagamento, ele teve seu mandado de prisão expedido e a Polícia teve que entrar na favela. Segundo o presidente, a mãe da criança teve "uns problemas" com os traficantes, evitando contar que tipo de dificuldade ele estava se referindo.

Como ele relata, a Associação é buscada pelos moradores quando necessitam de respostas que apenas o Estado poderia prover. Mesmo com a existência de uma grande força de controle territorial exercido por um poder paralelo, este não tem legitimidade para fornecer às pessoas a posse de uma propriedade, permitindo que os moradores tenham o mínimo de legalidade, sendo também incapaz de promover os serviços básicos de água, esgoto, eletricidade, educação e saúde que são reclamados como dever do poder público em suas diferentes escalas de gestão. Na medida em que passa a ser função principal da Associação de Moradores exercer pressão por políticas públicas, a ASSII exerce um papel-chave de intermediação entre as instituições e os moradores, tarefa que, apesar de práticas escusas de conhecimento geral entre traficantes e instituições do Estado como a polícia, não é possível de ser realizada pelos grupos que controlam a favela.

Sem embargo, por essa mesma razão, é difícil a separação da ASSII e do tráfico de drogas na favela. O líder analisa que a existência da Associação deu força ao tráfico de um modo totalmente inesperado: ao colocar nas costas do líder da ASSII a função de chamar o Estado para promover melhorias sociais, diminuiu-se a pressão que os moradores faziam sobre os traficantes e facilitou sua existência ao aumentar suas vantagens (em uma possível atenção maior despendida com estratégias de venda de drogas) e diminuir seus encargos como líderes. A relação entre um líder de uma Associação de Moradores e grupos que controlam o território já é amplamente conhecido e nesse trabalho de campo isso também apareceu.

Assim como ocorre na primeira associação analisada, o líder da ASSII construiu um vínculo com o mesmo vereador. Sem querer entrar no assunto, o líder da ASSII declarou trabalhar também no gabinete do tal vereador, mas "um trabalho à distância", cujo salário é o principal provento de sua família. Não ficou claro qual função exerceria, pois, em todos os momentos nos quais o tema era abordado, o presidente desconversava e não respondia. Era um assunto claramente constrangedor. Entretanto, em um ambiente que poderia ser hostil à presença de carreatas políticas, propagandas e corpo-a-corpo, o vereador conseguiu terreno livre para conversar com moradores em um dos dias de trabalho de campo na favela.

A relação com o tráfico de drogas era ainda mais nebulosa. Ao questioná-lo sobre a necessidade de novas eleições, ele respondeu: "Não precisa porque todos gostam do meu 
trabalho. Todos. Até esse pessoal [os narcotraficantes] me apoia em meu trabalho". Sua eleição por 42 votos (uma representatividade de menos de $0,5 \%$ da população geral) sem nenhum adversário, a falta de novos processos eleitorais e o apoio dos grupos de narcotraficantes levantaram questões importantes sobre a legitimidade e até mesmo legalidade desse representante.

Mais uma vez, o trabalho de campo levantou importantes questões para a pesquisa, mas, por outro lado, criou dificuldades para sua operacionalização. A proximidade do líder da ASSII com o poder paralelo dos narcotraficantes e também a relação com o vereador tornaram impossível qualquer tipo de mapeamento. Em ambos os casos, além da questão ética em respeitar o pedido de anonimato, a própria segurança como pesquisador estava em jogo. Como já dito na introdução, essa dificuldade metodológica não é tão relevante para outras ciências humanas que não têm o espaço geográfico como foco de análise. Ficou claro que esse impasse era um problema para a própria identidade da ciência geográfica e não apenas um problema de operacionalização.

\section{O ESPÍRITO GEOGRAFICO NA TRÍADE LOCALIZAÇÃO-DESCRIÇÃO-REPRESENTAÇÃO}

Ao longo da história do pensamento geográfico, distintas definições foram apresentadas sobre o que seria seu principal objeto de investigação, remetendo não apenas à institucionalização da disciplina no século XIX, mas também às suas raízes mais antigas. Ler o passado da disciplina pressupõe considerar suas dualidades internas, sejam elas nomeadas sob à distinção entre geografia nomotética e a idiográfica (HETTNER, 2011a, [1929]; GOMES, 1996; CLAVAL, 2014; VESENTINI, 2010), pelas filiações diversas produzidas pelas sociedades de geografia e pela universidade (SCHULTEN, 2001; MOREIRA, 2010), a partir da dicotomia estabelecida (e muito combatida) da geografia humana e a geografia física, ou, ainda, nos discordantes conceitos que seriam considerados chaves no pensamento geográfico, para citar os clássicos, como a paisagem, em Otto Schluter ou em Siegfried Passarge; a região em Vidal de la Blache; o território em Claude Raffestin e Robert Sack, o espaço em A. Hettner; ou, ainda, o lugar em Yi-Fu Tuan.

Nesse artigo, defende-se que a tríade localização-descrição-representação é o elemento epistemológico que perpassa todo o conhecimento geográfico, mesmo levando em consideração as grandes compartimentações realizadas pelos historiadores da disciplina. Essa é, para nós, a ponte ontológica geográfica que nos ajudaria a compreender o impasse metodológico na pesquisa apresentada anteriormente. É possível afirmar, usando um termo caro à escola francesa de geografia do início do século $\mathrm{XX}$, que essa tríade representa 0 espírito geográfico por excelência. Por essa razão, não cabe nesse trabalho a aventura de trazer as contradições e críticas em relação às definições já feitas da Geografia, historiografia que demandaria outro esforço a partir de objetivos distintos. Por não se pretender esgotar o tema, os dilemas epistemológicos da disciplina (BAULIG, 1982; CAMARGO e ELESBÃO, 2004; LIVINGSTONE, 2008 [1992]) não serão, pois, aqui, objeto de análise. A ideia é revelar de que modo a tríade perpassa as mais distintas definições realizadas da Geografia e, com isso, demonstrar como o dilema metodológico enfrentado na pesquisa de doutorado perpassa valores ontológicos da disciplina e não seria apenas uma questão de operacionalização de pesquisa.

A ideia que fazer geografia pressupõe a localização, a descrição e a representação atravessa todos esses dilemas epistemológicos. Para nos atermos apenas aos grandes clássicos da Geografia e alguns importantes autores contemporâneos, é possível dizer que esses três elementos são, direta ou indiretamente, fundamentais para a construção do saber geográfico em suas mais diferentes perspectivas. Apesar de ser conhecida a dificuldade em periodizar a história de uma ciência, especialmente a geográfica (LIVINGSTONE, 2008 [1992]), para os objetivos traçados nesse artigo, aceitar-se-á aqui a divisão em períodos feita por geógrafos (MORAIS, 1985; CÔRREA, 1995; GOMES, 1995) correspondentes às grandes mudanças históricas da disciplina, a ver: Geografia Tradicional (1870-1950), Geografia TeoréticoQuantitativa (1950-1970), Geografia Crítica (1970-...), Geografia Humanística (1970-...) e, por fim, o que denominamos de pluralidade epistemológica contemporânea.

$\mathrm{Na}$ denominada Geografia Tradicional, é possível perceber a localização como atributo espacial de importância fundamental para as pesquisas desenvolvidas. Apesar de apontar a diversidade do pensamento geográfico francês, Berdoulay (2017 [1981]) revela que a localização sempre foi fundamental para a interpretação do mundo pelos geógrafos franceses.

$\begin{array}{llllll}\text { Caminhos de Geografia } & \text { Uberlândia - MG } & \text { v. 20, n. } 70 & \text { Junho/2019 } & \text { p. 599-618 Página } 605\end{array}$


Por exemplo, quando um fenômeno ou uma área eram estudados, deveriam sê-lo em função de sua posição relativa e de sua comparação com fenômenos e áreas semelhantes no mundo (BERDOULAY, 2017). A comparação entre os trabalhos de Max Sorre, Vidal de La Blache, Camille Valleux e J. Brunhes forma um exemplo interessante.

Max Sorre, apesar de dissonante em diversas características do que se denomina como Geografia Tradicional, apresenta concepções do espaço geográfico como também espaço absoluto. Ele afirma que "o espaço geográfico é primeiramente este espaço geodésico" (SORRE, 1984 [1943], p. 141, grifo nosso) e, por isso, localização, configuração e divisão são noções que aparecem em todos os conceitos espaciais. Apesar disso, Sorre demonstra que esse espaço geométrico não é tudo. Elementos de ordem psíquica tornariam o espaço geográfico também espaço relativo e relacional.

De modo diferente, Vidal parte por uma perspectiva holística, na qual as pesquisas dos conjuntos e dos fenômenos correlatos eram fundamentais, mas também se refletia nas obras dos outros dois autores, Camille Valleux e J. Brunhes. Eram, pois, a partir dos estudos regionais que elas se manifestavam melhor, mas estavam longe de se limitar a eles (CAPEL, 1977). Berdoulay (2017 [1981], p.54) afirma que, para Vidal, "o trabalho de análise devia concentrar-se na localização [...]. As múltiplas facetas desse 'espírito geográfico' eram mais bem captadas em suas consequências". Não à toa, que sua frase mais famosa afirmava que a geografia seria a ciência dos lugares e não dos homens. Paul Claval (2014) defende que havia dois fatores que produziam a especificidade do geógrafo francês: o lugar que ele conferia às paisagens e, numa escala que não é mais a da observação direta, mas a do mapa, a atenção concedida às formações de densidade. Para tanto, o autor, busca superar a dicotomia geografia física/geografia humana por meio do conceito de região (BALLESTEROS, 1983).

É a partir do método descritivo que Vidal de La Blache constrói sua geografia regional (CLAVAL, 2014). Inspirado abertamente nos trabalhos de Alexander von Humboldt, cujas pesquisas valorizavam a observação direta e a descrição detalhada (GOMES, 1996), o geógrafo francês tornou a explicação e a descrição como duas vertentes de uma única mesma ideia, isto é, o método vidaliano é caracterizado por três proposições: descrição a partir da observação, comparação e conclusão (GOMES, 1995). Em 1903, em Tableau de la Géographie de la France, Vidal fez um apelo "a um gênero de descrição que parte de uma compreensão produzida por imagens geográficas" (GOMES e BERDOULAY, 2018, p.360). A descrição, por outro lado, não tentava abarcar a todos os elementos de uma região, pois, para ser configurada como científica, ela seria, inerentemente, seletiva, flexível e variada com seu próprio objeto. O método, portanto, indicado para desvendar a combinação de fatores responsável por sua configuração é a descrição, "pois só através dela é possível penetrar na complexa dinâmica que estrutura o espaço" (La Blache apud GOMES, 1995).

Ao preocupar-se com as pesquisas geográficas regionais que não exerciam comparações gerais, os trabalhos de Brunhes priorizavam as conexões entre os lugares e como essa interação produziria regiões passíveis de classificação e comparação. Para o autor, faz parte da construção do conhecimento geográfico o seu georreferenciamento, para usar termos atuais. Entretanto, a simples distribuição dos elementos na superfície da Terra não constituiria a essência do fazer geográfico; para ele, a localização e a relação com outros pontos da Terra, isto é, a compreensão do estar-junto e atuar-junto dos diferentes espaços do planeta era função principal do geógrafo. A localização de um objeto na superfície terrestre não seria, apenas, uma curiosidade espacial, para saber onde se está, mas, o onde do fenômeno faria parte da sua própria explicação, a partir de suas relações espaciais. É por essa razão que o conceito de conexão se fez tão presente em sua obra.

Castillo (2017) revela a importância do trabalho desse autor francês para a geografia contemporânea. Afetadas pela segmentação da disciplina ocorrida ao longo do século XX, o geógrafo teria perdido uma competência histórica de sua profissão: capacidade de analisar as conexões e relações espaciais, capaz, portanto, de interpretar a complexidade do ser humano e suas distintas sociedades construídas. Perdeu-se, assim, a noção do espaço como "uma totalidade dinâmica, integrada e complexa" (CASTILLO, 2017, p.255). A originalidade de Brunhes estaria exatamente em não se encaixar nas segmentações existentes à época, transformando-se em um geógrafo independente desses paradigmas (MOREIRA, 2010). A ideia de conexão deveria, pois, guiar a interpretação dos fatos geográficos, superando a dicotomia existente entre sociedade-natureza. São, portanto, duas ideias sobre conexão: uma 
ligada à relação entre elementos humanos e naturais; outra ligada à conexão entre os espaços. Nas duas, a localização é um elemento estruturante. Em resumo, é importante destacar que a localização dos fatos geográficos nessa concepção não se refere apenas às coordenadas geográficas, mas sim que as suas localizações são parte sine qua non para a compreensão das conexões existentes entre os elementos que o ajudam a explicar.

É também nesse sentido que é possível conhecer o trabalho do geógrafo alemão Hettner. Para ele, a Geografia não seria apenas a ciência do onde das coisas, isto é, a localização em si é importante, mas não conduziria a principal função de uma pesquisa geográfica (HETTNER, 2011a [1927], p.148), assim "nenhum fenômeno da superfície terrestre pode ser pensado apenas para si, ele só se torna compreensível por meio da concepção de sua posição em relação aos outros pontos da Terra". E, pois, na "natureza da localidade" que estaria o caráter geográfico, pois só a Geografia estaria sincronizada com as conexões internas causais de todos os fenômenos unificados num lugar (HETTNER, 2011b [1927]). Apesar de ser considerada uma ciência da totalidade, é no caráter geral das regiões que se revelaria a interação e a coexistência entre os fenômenos.

O autor também confere à descrição um papel importante dentro da construção do saber geográfico. Hettner afirma que

\begin{abstract}
Nós podemos denominar ambas, história e geografia, do mesmo modo, como uma descrição, mas com a diferença de que a primeira é uma descrição no tempo e a segunda, uma descrição no espaço. A história se refere aos acontecimentos que, em relação ao tempo, sucederam-se um após o outro. A geografia se refere aos fenômenos que, em relação ao espaço, acontecem ao mesmo tempo. A História é uma notícia de acontecimentos que se sucedem um após o outro e têm relação no tempo. A Geografia não é senão uma notícia dos acontecimentos que caminham um ao lado do outro no espaço. A história é uma narrativa; a geografia, uma descrição. (HETTNER, 2011b [1927], p.142).
\end{abstract}

Hettner, por outro lado, afirma que a Geografia não seria uma "simples" descrição. A busca pelas causas conduziria a mera descrição a se transformar em uma "descrição explicativa" ou "descrição interpretativa". Em resumo, Hettner confere à Geografia o status de ciência corológica, responsável por conhecer o caráter das regiões e lugares, a partir do método descritivo interpretativo.

F. Ratzel, reconhecido como pai da Geografia Política, e os primeiros geopolíticos como Mackinder, também tinham na localização e na descrição dois atributos explicativos para seus objetos de estudo. Este último, por exemplo, considerava a descrição como um dos principais fins da ciência geográfica (DAVIS, 1909). Para não entrar em outros autores importantes da geopolítica (como Alfred Mahan, James Fairgrieve, Nicolás Spykman), o trabalho sobre o território pivô ou "Heartland" continental, é uma marca indubitável do papel da localização e descrição de territórios para as estratégias geopolíticas (BACA, 2005). Já para Karl Haushofer (AGNEW e MUSCARÀ, 2012), a palavra geopolítica se referia aos modelos construídos baseados nas relativas posições globais das grandes potências e a consequente necessidade de estabelecer áreas de influência para alimentar suas urgências de expansão.

Apesar da afirmação que autores fizeram a respeito de Ratzel como "pai do determinismo ambiental" (MORAIS, 1985) já ter sido amplamente criticada pelo seu modo simplista de ver a vasta obra desse geógrafo alemão (SANGUIN, 1981; BASSIN, 1987; SEEMAN, 2012), seu trabalho sobre a relação entre Estado e espaço é fundamental para entendermos as raízes da Geografia Política. Ao destacar características puras do espaço, como, os comprimentos, os distanciamentos, a forma e o tamanho das superfícies, em direta oposição às diferenças no conteúdo, o autor é responsável por trazer as básicas categorias geográficas - como localização - para explicar o nível de desenvolvimento dos Estados. Como afirmam Agnew e Muscarà (2012, p.21), ao colocar o Estado como central para a geografia, toda a abordagem de Ratzel partia da premissa que a posição do Estado ou sua localização em relação aos outros Estados, tornava-o mais ou menos vulnerável para a expansão territorial de outros. Assim, a partir dessa característica geográfica, Ratzel se colocou também no debate entre o darwinismo e lamarckismo, ao enfatizar o papel do espaço na evolução das espécies. 
A apreciação estética via descrição é outro ponto importante da obra de Ratzel. Para Seeman (2012, p.5) foi a viagem que esse autor fez para os EUA e para o México (1873-1875) que transformaram o Ratzel zoólogo para o Ratzel geógrafo, "trocando o conceito de espécie pelo conceito de espaço". Entretanto, diferentemente de alguns seus contemporâneos francesas, Ratzel não considerava a Geografia como descrição da Terra, mas como ciência em movimento. Ratzel (apud Seeman, 2012, p.11) afirmou que: "não está na natureza da geografia de se ocupar apenas com fenômenos imóveis. Ela registra a situação de qualquer objeto e obtém assim as situações que seguem". Desse modo, a descrição, apesar de um status e um objetivo diferenciado, também se configura como um importante método na geografia ratzeliana.

Localização e descrição se juntam de um modo muito interessante nas teses produzidas por geógrafos tradicionais no século XIX. Era comum entre eles realizar grandes viagens, ora financiadas pelas sociedades de geografia, ora pelas próprias universidades, e produzirem um trabalho final sobre o espaço visitado. Vê-se, portanto, que o status do trabalho de campo na geografia perpassa toda a história de produção de conhecimento geográfico. Os grandes clássicos da Geografia, como Kosmos de Alexander von Humboldt ou textos não tão comentados de geógrafos conhecidos, como Desde México - apuntes de viaje de los años 1874-1875, de F. Ratzel, já revelavam a interessante imbricação entre descrição e análise espacial. As teses de doutoramento dos geógrafos clássicos eram, geralmente, descrições e análises de viagens realizadas, como é possível ver em $O$ Clima do Chile e do Oeste da Patagônia, em 1879, de A. Hettner (SAHR e ARANTES, 2011). A geografia dos viajantes faz parte, pois, da própria essência da ciência.

Já nos Estados Unidos, na geografia de Harsthorne o espaço é visto como o espaço absoluto, isto é, um conjunto de pontos que têm existência em si, sendo independente de qualquer coisa (CÔRREA, 1995; BESSA, 2010). Foi no trabalho desse autor que o conceito de região foi impulsionado e ganhou força também no continente americano, consolidando-se como uma das principais chaves interpretativas da ciência naquele momento. Já em sua tese de doutorado The Lake Traffic in Chicago e em suas posteriores aulas ministradas em Geografia Econômica, percebe-se a importância dada para a localização como um fator em si explicativo. Suas publicações na área abordavam temas localizacionais, como, por exemplo, a localização das indústrias de ferro e aço (COSCIONI, 2017). A partir de um interesse expandido para a Geografia Política, o autor escreve sobre principal obra, The Nature of Geography (1939), na qual teve a ambição de discutir os aspectos epistemológicos que guiavam a ciência geográfica. Harsthorne definiu a geografia como a ciência que interpreta as realidades da diferenciação de áreas do mundo, tais como elas são encontradas (HARTSHORNE, 1939), tornando, assim, a localização um fator fundamental na função do geógrafo em diferenciar as áreas na superfície terrestre. Também na ideia de geografia como ciência de síntese, a descrição exercia papel fundamental, transformando-se, também, em um dos métodos principais utilizados pela Geografia Regional. Para Hartshorne, o método regional era necessariamente empiricista e descritivo, e a distribuição espacial dos fenômenos caracterizaria as unidades regionais, aproximando as pesquisas geográficas de um caráter idiográfico em interessantes monografias regionais.

Em 1915, W. M. Davis escreveu seu artigo Os princípios da descrição geográfica, no qual discute a importância de descrever usando o tempo verbal no presente, isto é, tentar afastar da geografia a tendência a descrição como uma narração histórica dos eventos que explicam o presente. Comentando esse trabalho, Darvy (1962) analisa como - apesar de haver uma grande dificuldade em definir o método geográfico e seu objeto - a descrição sempre foi uma das características fundamentais da Geografia, contida, inclusive, no significado do seu próprio nome. A ideia que o geógrafo "descreve a Terra" remeteria aos gregos e nunca teria sido afastada como método na Geografia. A sua proposta foi apresentar cinco modos de combinar descrição e explicação, claramente para afastar as críticas já existentes sobre o método descritivo como um fim em si mesmo (a tradição da "pintura de paisagem", como ele denomina).

Brunhes (1962, p.54), já anteriormente citado, aproxima a geografia da localização-conexão com a observação-descrição como método. Portanto, para ele, seria importante observar, classificar os fatos e destacar categorias e, posteriormente, tecer comparações "destes fatos destacados em uma série de casos análogos ou vizinhos ou progressivamente distintos" e, por essa razão, o autor já usava de técnicas como fotografias, desenhos panorâmicos, utilizados em sua argumentação científica marcada por "uma forte inter-relação entre os discursos verbal e iconográfico" (CASTILLO, 2017, p.255). 
Essa importância da localização como fator estruturante na explicação de fenômenos sociais atravessa toda a história do pensamento geográfico. É possível perceber, apesar de modo diferente, como essa categoria espacial é importante também para a denominada Geografia Teorético-Quantitativa, a Geografia Crítica e, até mesmo, para a grande pluralidade metodológica e epistemológica da geografia do final do século XX e início do século XXI.

No primeiro, o espaço se tornou o conceito-chave da geografia, deixando de lado a paisagem e a região, e colocando a ideia de distância como característica geográfica fundamental, realçando, assim, tanto a ideia de espaço absoluto quanto a de relativo (CÔRREA, 1995). A busca pela cientificidade aproximou a Geografia das ciências naturais, especificamente a Física, que havia se tornado o exemplo de ciência a se seguir. Imersa na onda neopositivista recorrente no contexto acadêmico (AMORIM FILHO, 1999), os modelos explicativos se tornaram recorrentes (os de Von Thunen, talvez, sejam os mais expoentes), como os da escola de Chicago para a geografia urbana que buscavam regras gerais para a compreensão da organização interna das cidades. No conceito de espaço absoluto, o espaço tornou-se sempre idêntico e imóvel, constituindo-se no receptáculo que contém as coisas. Toda a mecânica newtoniana se desenvolveu a partir da teoria do espaço absoluto, pois ele seria o requisito necessário para poder explicar o estado de repouso e o movimento retilíneo uniforme. Para Newton, portanto, "o espaço tinha existência própria e independente dos corpos que contém" (JAMMER, 2010, p.146). Torna-se claro aqui a ruptura provocada por essa concepção de espaço nas teorias newtonianas em relação ao aristotelismo. O espaço newtoniano existe independente do objeto.

O interesse pela diferenciação espacial (BESSA, 2010) era evidente, apesar de pensar essa tarefa de modo diferente da Geografia Tradicional e da Geografia Crítica. Mesmo tendo sofrido intensas críticas pela Geografia Crítica e seus métodos terem praticamente desaparecido durante os últimos quarenta anos, é importante destacar que está, atualmente, ressurgindo o interesse pela localização de fatos geográficos a partir da noção de distância. López et al (2009) apontam a fricción de la distancia como uma das responsáveis pelo processo de convergência regional no centro do México. Fricción de la distancia significa: "a distância associada a uma decisão (ir ao trabalho, fazer compras, etc.) está condicionada por uma série de fatores, como o esforço, a energia e o dinheiro requerido para realizar o trajeto de distância" (LÓPEZ et al, 2009, p.74). Desta perspectiva, argumenta-se que a quantidade de interações espaciais associadas a um problema de decisão ocorreria em maior número sobre distâncias curtas e diminuiria conforme aumentassem as distâncias. Percebe-se, pois, que a localização de pontos em um plano e suas relativas distâncias formariam parte estruturante na explicação de um fenômeno social, algo que se reflete também na mudança de concepção do conceito de região, como evidencia Gomes (1995).

Interessante notar que tanto no momento que consideravam a região como um produto da geografia, quanto quando ela se transformou em um meio, a descrição exerce um papel fundamental. Obviamente, o status e o objetivo da descrição se modificam, mas em ambos não se descarta a importância do método descritivo. Nas monografias regionais, "descrever associava-se à necessidade de identificação in loco dos fenômenos", ou seja, "era necessário estar em contato com o objeto, reconhece-lo através de evidências concretas, tocá-lo e vivenciá-lo" (RIBEIRO, 2010, p.15); Já nas denominadas análises regionais da Geografia Teorético-Quantitativa, quando a região é vista como classe de área (GOMES, 1995), critérios de classificação e divisão do espaço são uniformes, e só se interessa neste espaço por aquilo que é geral, que está sempre presente. O fato particular, o único ou excepcional, não seria do domínio da ciência segundo esta perspectiva, entretanto, a descrição acurada dos fatores utilizados para a classificação de áreas (de modo racional, como defendem os geógrafos teorético-quantitativos) é fundamental para a objetividade de uma pesquisa.

Já na Geografia Crítica, sob influência marxista, a localização ganhou outro enfoque. Em busca de revelar a geograficidade inerente da interpretação materialista-dialética do mundo, apesar de Marx e seus discípulos terem colocado o tempo como categoria superior ao espaço a partir da discussão hegeliana da História, Soja (1993) e Lefebvre (1999 [1970]) são expoentes ao afirmarem que a espacialidade seria a expressão material das relações sociais. Para este último autor, o espaço não seria uma coisa, mas um conjunto de relações (LEFEBVRE, 1999 [1970], p.83). A ideia de espaço como substrato possuiria, para ele, sérias consequências, como a assimilação do espaço a uma coisa. Segundo Lefebvre, o espaço não seria uma coisa em si, um objeto, assim, o autor critica a ideia de espaço absoluto e afirma que ele existe a partir das relações. Configura-se, assim, um diferente modo de análise sobre a diferenciação espacial e um debate novo sobre o fator localização, sendo tomado em uma ideia de espaço relativo e relacional, e não mais absoluto (CÔRREA, 1982), apesar de não o abandonar por completo.

$\begin{array}{llllll}\text { Caminhos de Geografia } & \text { Uberlândia - MG } & \text { v. 20, n. } 70 & \text { Junho/2019 } & \text { p. 599-618 Página } 609\end{array}$


Em Justiça Social e a Cidade (1977), Harvey utiliza o conceito de espaço absoluto para entender a maneira que a propriedade privada funciona na sociedade capitalista. Isso nos demonstra que a ideia de espaço absoluto tão trabalhada em Hartshorne não foi expurgada na Geografia Crítica e possui grandes contribuições de reflexões. Para Harvey, na sociedade capitalista, todos os outros espaços são relativos ao espaço absoluto da propriedade privada, tendo seus valores de uso e troca definidos a partir dessa ideia. Assim, "o movimento de pessoas, bens, serviços e informações verifica-se em um espaço relativo porque custa dinheiro, tempo e energia para se vencer a fricção da distância" (HARVEY, 1977, p.13). A localização da terra seria, pois, fator fundamental para a análise do seu valor de uso e de troca.

Cabe destacar, ainda, a importância ímpar do trabalho de Immanuel Wallerstein para a localização como uma categoria espacial de análise econômica. A noção que os espaços são conectados na estrutura do capital é a base explicativa para a teoria do sistema-mundo, na qual categoriza os países em centrais e periféricos. Assim, analisar a localização de um espaço ou de uma atividade como, por exemplo, a localização das indústrias em um país, é perceber que, a partir da complexidade do mundo globalizado, o plano local se acha cada vez mais invadido pelo plano global (CARLOS, 2001), acentuando a fragmentação do espaço e as desigualdades socioespaciais. Em suma, a localização a partir de uma visão estruturalista marxista do mundo, precisa ser considerada a partir de suas relações traçadas em planos que fogem ao local - cabe, ao geógrafo, desvendar essas esferas que estão por trás do que é visto. A localização de espaços que mandam e espaços que obedecem (SANTOS, 1997) precisa ser analisada a partir da lógica de acumulação primitiva do capital, como se percebe o interessante trabalho de Milton Santos em O trabalho do geógrafo no Terceiro Mundo (2010 [1971]).

A Geografia Humanística e Cultural, por sua vez, ao lidar com o espaço vivido (FREMONT, 1980), analisava a localização a partir dos valores subjetivos de indivíduos e grupos, isto é, de que modo era vivenciado, pois essa vertente da ciência geográfica está "assentada na subjetividade, na intuição, nos sentimentos, na experiência, no simbolismo e na contingência, privilegiando o singular e não o particular ou o universal e, ao invés da explicação, tem na compreensão a base de inteligibilidade do mundo real" (CÔRREA, 1995, p.30). Apesar da grande diversidade epistemológica que essa vertente recebeu (como a Fenomenologia e a Hermenêutica), é interessante notar em diferentes trabalhos sobre Geografia da Religião, como a localização de espaços sagrados e profanos, além dos itinerários de romarias e procissões, são elementos analíticos geográficos de suma importância nas pesquisas desses geógrafos (ROSENDAHL, 1995).

Interessante perceber que noções geográficas fundamentais para outros períodos geográficos ganham roupagem nova e voltam a ser utilizados nessa corrente. É o que ocorre com a ideia de distância, elemento fundamental, como anteriormente apresentado, na Geografia TeoréticoQuantitativa e, sob a ótica de Yi Fu-Tuan, orienta-se e se estrutura pela intencionalidade do ser. Como Holzer (2003, p.118) apresenta, "se por um lado esta espacialização da matéria exige um comportamento ativo, por outro, o homem é feito pelo ambiente geográfico. A distância é um elemento primordial deste ambiente que age sobre o homem, sendo assim primordial para a estruturação do mundo que nos rodeia". Diferentemente do período anterior, entretanto, a distância não seria medida de modo absoluto, mas a partir da sensação que o homem carrega nele, isto é, a "distância não é experimentada como uma quantidade, mas como uma qualidade exprimida pelos termos perto e longe" (DARDEL, 2011 [1952], p.14).

A descrição, para os geógrafos humanistas e culturais, perpassa a interpretação subjetiva, dedicando-se à geografia da percepção e construção de mapas mentais, como seu principal modo de representação, como apontaremos a seguir. Desde a influência fenomenológica sofrida por C. Sauer (HOLZER, 2003; 2016), a descrição aparece como um método fundamental para a compreensão das realidades subjetivas. Não era importante, pois, a construção de um caráter científico para o método descritivo, muito pelo contrário, a crítica do cientificismo era muito presente nessa corrente de pensamento (DARDEL, [1952]). Yi Fu-Tuan (1971) é um nome importante na defesa da descrição do mundo cotidiano como método da geografia incorporados no conceito de lugar, como principal chave interpretativa para essa corrente de pensamento.

Interessante perceber o caminho pelo qual a Geografia está caminhando atualmente. Há um debate intenso sobre a segmentação da Geografia em suas duas grandes áreas de conhecimento e o cientificismo positivista que criou subcampos nas ciências, a ponto de se perder a totalidade do fenômeno. Há, portanto, uma revisita aos clássicos da Geografia Tradicional que haviam sido deixados de lado por praticamente toda segunda metade do século XX. Em Souza (1997), Souza (2016), Suertegaray (2017) e Azevedo (2017), é possível identificar, por exemplo, como a teoria da complexidade, principalmente inspirada nos trabalhos 
do filósofo Edgar Morin, estaria ajudando a geografia a tentar superar a compartimentação construída dentro da disciplina. Mesmo havendo autores que criticam essa tentativa de complementaridade entre geografia física e geografia humana, como por exemplo Gomes (1997, p.36) que afirma, categoricamente, "o que estamos afirmando é que não há unidade ou complementaridade entre a Geografia dita física e a Geografia humana", é possível perceber uma profusão de trabalhos contemporâneos que buscam a construção dessa ponte, desde aqueles autores com perspectivas epistemológicas mais próximas ao marxismo (QUAIANI, 1979; CÔRREA, 2010; MOREIRA, 2006) ou mesmo em textos oriundos da geografia física (ROSS, 2009).

A localização passa a ser vista a partir de uma pluralidade teórico-metodológica, buscando, na Geografia Tradicional, Teorético-Quantitativa, Crítica e Humanista, reflexões que ajudem na compreensão de um fato geográfico (MOREIRA, 2006). Os trabalhos sobre o espaço público em Gomes (2006; 2013) refletem essa característica contemporânea pela busca de conceitos tradicionais da ciência geográfica - tamanho, localização, densidade - nos estudos de temáticas atuais. Na Geografia Política, por exemplo, ao discutir a materialidade do espaço político (AZEVEDO, 2018a; AZEVEDO, 2018b; CASTRO, 2018), os autores revisitaram temas caros à Geografia Teorético-Quantitativa, como a noção de distância e densidade. Debates contemporâneos, por exemplo, sob o prisma de conceitos como "diferenciação espacial" (BESSA, 2010) nos remete a diferentes momentos epistemológicos da disciplina, apesar de décadas de distanciamento e, consequentemente, novos aportes teóricos-metodológicos. É cada vez mais defendida a tese de que não existe uma metodologia para uma geografia, mas sim metodologias para geografias distintas.

Seja a descrição como fim último da Geografia, seja ela um momento apenas da pesquisa geográfica, o que importa, aqui, é que é inerente da tarefa de espacializar a descrição, seja como fim ou como meio. Descrições bem produzidas por geógrafos, funcionam, em si mesmas, como importantes imagens construídas para uma interpretação geográfica dos fenômenos sociais. Em outras palavras, a descrição pode ser, ela mesma, um modo de representação.

Destaca-se que não se faz necessário aqui debater a própria noção de representação, que tem uma história densa de controvérsias (para um estado da arte sobre o tema, ver GAMBARATO, 2005). Assim, representação é tomada em sua acepção mais simples, isto é, em sua semântica trazida por definições gerais, como no Dicionário Aurélio, de "reproduzir a imagem de; refratar; refletir; representar a natureza". Como último elemento da tríade apresentada, a representação é, talvez, o atributo mais controverso atualmente dentro da ciência geográfica. Encontram-se, hoje, geografias que se buscam "non-representational', como se percebe em Nigel Thrift (GOMES e BERDOULAY, 2018). Importante destacar que como representação não estamos, aqui, nos limitando aos mapas, apesar de ele ser um importante meio de representação geográfica. A representação pode ser feita através de diferentes tipos de imagens - fotografias, pinturas, filmes, etc. Em um artigo atual, Gomes e Berdoulay (2018) criticaram a onda contemporânea que vê com maus olhos o uso de representações de um modo geral como modo de alcançar o conhecimento. Nesse trabalho, eles revelam que passou a predominar na ciência geográfica uma ideia de que as representações ocultavam a realidade, a partir de escolhas intencionadas dos autores que as usavam. Assim, desde mapas com a conhecida discussão sobre o uso político das projeções cartográficas (BLACKSELL, 2010) ou mesmo fotografias (COSGROVE, 2008), a ideia é que eles seriam elementos ideológicos que precisavam ser desvendados pelos geógrafos na busca de uma verdadeira interpretação sobre o real.

\title{
Entretanto, aqui se concorda com os autores citados ao afirmarem que
}

\begin{abstract}
Os elementos encontrados em um quadro assim como em um mapa, não o são pelo tamanho ou volume, mas sim pela associação que desejamos expressar para fins de uma argumentação ou como base de uma explicação. Por isso, não há qualquer sentido em avaliar a consistência de uma imagem pela suposta semelhança com um referente. A análise que deve ser feita é aquela que se interroga sobre a coerência daquela imagem dentro da temática que está sendo tratada. A pergunta fundamental é: o que aquela imagem nos faz ver? (GOMES e BERDOULAY, 2018, p.360)
\end{abstract}

Assim, a imagem, em seu sentido amplo, por sua capacidade de representar, é parte constitutiva da realidade com interessante poder de transformação. Rose (2007) apresenta abordagens para a interpretação de materiais visuais das representações, afirmando que um autor que utiliza de certa imagem apresenta o mundo que é trazido à sua consciência, que, além de ser um modo de visualização de um fenômeno, é, portanto, em si, um objeto de

$\begin{array}{llllll}\text { Caminhos de Geografia } & \text { Uberlândia - MG } & \text { v. 20, n. } 70 & \text { Junho/2019 } & \text { p. 599-618 Página } 611\end{array}$


investigação e análise. Uma fotografia, um mapa, uma pintura, são modos de representações utilizados historicamente pelos geógrafos e, negá-los seria, defendemos, um ataque à própria ciência geográfica, ou, em outras palavras, a representação pode ser vista como um produto ou um processo na interpretação geográfica de fenômenos sociais (KOZEL, 2001).

Em 1669, a famosa pintura O Geógrafo do holandês Johannes Vermeer retrata de um modo interessante a função desse pesquisador, antes mesmo da institucionalização da Geografia como ciência. O rapaz, com um compasso na mão, observa o mundo pela janela e o reproduz no papel que está em uma bancada. A partir da pintura do rosto de um modo que remete a uma sensação de movimento, o autor nos leva a crer que o geógrafo olha pela janela, observa e diretamente reproduz o que está vendo sobre o papel, como se fosse um artista pintando uma natureza morta ou um nu artístico. Essa concepção de geografia se aproxima muito com o que Hettner denomina "geografia como arte" (HETTNER, 2011b). Stone (apud SEEMAN, 2009) explica que a luz que entra pela janela em direção ao geógrafo, corresponderia a uma metáfora para a iluminação que torna o mundo visível e penetra sua compreensão.

O mapa, como, talvez, o mais importante meio de representação do espaço, é associado historicamente ao imaginário social com a profissão de geógrafo. Em o livro infantil mundialmente conhecido O Pequeno Príncipe, o personagem principal da ficção encontrou um geógrafo no sexto planeta da sua viagem. O cientista, absorto em livros imensos, explicou que o geógrafo seria "um sábio que conhece o sítio onde se encontram os mares, os rios, as cidades, as montanhas, os desertos". O velho sábio pede, então, que o Pequeno Príncipe descreva seu planeta para que ele consiga traçar a representação do lugar de onde ele teria vindo. Mas, não seria uma descrição de todos os elementos, mas apenas daqueles não efêmeros, que poderiam estar em seu livro e constar para toda a eternidade. Segundo o geógrafo da história, "nós [os geógrafos] descrevemos coisas eternas".

Localização, descrição e representação são, portanto, características importantes da Geografia, mesmo aquela descrita pelo senso comum, ou mesmo no período de préinstitucionalização da disciplina e no mundo contemporâneo. A obra Geógrafo Moderno, de Nikola Schiller, combina a obra do pintor holandês do século XVII com novas formas de representação do espaço, indicadas nas fotografias aéreas no interior do corpo do centro da imagem. Na Geografia Tradicional, a obra de Brunhes também é interessante também nesse sentido. Como Gomes e Berdoulay (2018) apontam, para o autor francês, a foto constituía uma prova objetiva de um tipo de fenômeno, ilustração submetida a uma razão classificatória que o autor utilizava, compreendendo que esse tipo de instrumento era mais do que uma simples ilustração: era possível destacar, também seu valor pedagógico.

É também o trabalho de A. Hettner fundamental para compreender a importância da representação espacial em forma de mapas para a geografia. Para o autor, as ideias não se definiriam apenas por sua essência, mas, em uma perspectiva da semiótica, também por sua representação. Sua proposição reside exatamente no meio da problemática semiótica entre significante e significado, entre representação e análise-explicação. Fazendo aqui a diferença entre pesquisa e apresentação para captar a essência do objeto geográfico (os fatos) através da experiência, por um lado e, por outro, através das representações em termos, livros e mapas, Hettner mostra sua sensibilidade para compreender a Geografia de forma semiótica. Como afirmam Sahr e Arantes

\begin{abstract}
Ele publica, em 1903, um artigo intitulado Grundbegriffe und Grundsätze der physischen Geographie (Conceitos fundamentais e princípios da Geografia Física) no volume 9 da sua Geographische Zeitschrift. Neste artigo, divide a Erdoberfläche (superfície terrestre), conceito cunhado por Richthofen, em uma wirkliche Erdoberfläche (superfície terrestre real) e uma mathematische Erdoberfläche (superfície terrestre matemática). Com esta operação semiótica Hettner separa o objeto científico da Geografia de sua representação, chamando atenção para as confusões a esse respeito existentes na época. Para ele, todavia, só o conjunto desses dois aspectos permite falar de fato de uma Ciência Geográfica (SAHR e ARANTES, 2011, p.112).
\end{abstract}

As críticas que ganhariam corpo na Geografia Crítica, já podiam ser vistas em comentários de geógrafos tradicionais como Camille Vallaux. De acordo com Gomes e Berdoulay (2018), esse autor francês também não hesitou em criticar o uso de imagens cartográficas como um instrumento válido para chegar a uma explicação geográfica. Na Geografia Crítica décadas depois, a desconfiança em relação à representação era evidente. Considerando o mapa como um veículo de comunicação de fenômenos geográficos, esse período da ciência passou a suspeitar desse objeto tradicional da Geografia como importante modo de reprodução de desigualdades socioespaciais. O livro de Yves Lacoste (1988), A geografia - isso serve, em

$\begin{array}{llllll}\text { Caminhos de Geografia } & \text { Uberlândia - MG } & \text { v. 20, n. } 70 & \text { Junho/2019 } & \text { p. 599-618 Página } 612\end{array}$


primeiro lugar, para fazer a guerra, inaugurou, talvez, essa perspectiva sobre os modos de representação - especialmente o mapa - na geografia. Como Girardi (2000, p.42) aponta, nesse trabalho, o geógrafo francês tece "muitas críticas ao método, procedimento e posições políticas da Geografia até então constituídas, recaem sobre os mapas e as atividades cartográficas [...], revelando as relações de poder institucionalizadas na prática cartográfica". Assim, a representação, apesar de seu caráter pejorativo na Geografia Crítica, continuava sendo importante para as pesquisas geográficas, como um meio de mudar estruturantes desigualdades socioespaciais a partir de novas representações trazidas por grupos minoritários e excluídos - como o famoso mapa do uruguaio Joaquín Torres García nomeado Nosso Norte é o Sul (1943), que trouxe a América do Sul "de cabeça para baixo" e se tornou um importante modo de criticar as representações hegemônicas. A Geografia Política feminista é, ainda, outro interessante exemplo de como construir representações não hegemônicas (para melhor debate sobre esse tema, ver PAINTER e JEFFREY, 2005).

O trabalho de Peter Taylor e Colin Flint em Geografia Política é exemplar nesse sentido. Os autores, a partir da consideração da economia-mundo de I. Wallerstein, constroem uma interpretação geográfica da democracia. Em Political Geography: world-economy, nation-state and locality (2011 [1985]), os autores trazem a análise do sistema-mundo para dentro da geografia política e criticam a concepção de um mundo com múltiplas sociedades. Baseandose na postulação clássica de Wallerstein (1985), os autores argumentam que as sociedades fariam parte de um todo e suas transformações não se dariam de modo independente. Ao trazer essa ideia para a análise da geografia política, Flint e Taylor apresentam escalas geográficas ligadas inerentemente a certos valores. A escala local, a escala nacional e a escala global seriam, respectivamente, as escalas da experiência, da ideologia e da realidade. Com a carga pejorativa peculiar da economia política em torno do conceito de ideologia, os autores afirmam que o Estado distorceria a realidade produzida pela escala global e seria o principal produtor de representações que deveriam ser reveladas pelos geógrafos. As representações trazidas, por exemplo, pela geografia eleitoral, cujos trabalhos são ricos em mapas da espacialização do voto, seriam uma "geografia do suporte" à democracia liberal, altamente criticada por essa vertente da geografia.

Todavia, talvez foi na Geografia Humanística e Cultural que uma reflexão mais profunda sobre a representação tenha tido mais força. Apesar de, como já se demonstrou, a representação ser uma característica fundamental da geografia em todos os tempos, é nesse período da ciência que a representação virou, de fato, uma problemática de pesquisa em si. Constrói-se, assim, uma Geografia das Representações que seria "uma Geografia do conhecimento simbólico. Assume as representações sociais como ponto de partida para uma Geografia Cultural do mundo banal, da cultura cotidiana, do universo consensual impactado pelo universo reificado da ciência e da política" (GIL FILHO, 2005, p.80).

É a partir dessa perspectiva, que a ideia de mapa mental (ou "mapa de significados") ganha força, especialmente no ensino da geografia no ensino fundamental e médio. Kozel (2005) aponta que trabalhar com essa perspectiva com alunos seria um importante método de compreensão das representações que eles trazem, pois se considera o aluno como um agente de representações. Sendo assim, "os mapas podem ser elaborados com objetivos variados, com o intuito de desvendar trajetos, lugares, conceitos e ideias" (KOZEL, 2005, p.145). É possível encontrar, em uma busca rápida na internet, abundantes trabalhos sobre o tema ainda atualmente, corroborando a ideia de pluralidade de perspectivas epistemológicas na Geografia contemporânea.

Sem dúvida, a geografia contemporânea, além de também problematizar o papel das representações na construção de conhecimento geográfico (como foi exposto em GOMES e BERDOULAY, 2018), tem em seu atual desenvolvimento o aporte de geotecnologias, como o uso de sensoriamento remoto e do Sistema de Informações Geográficas (SIGs), uma nova ênfase no papel das representações, especialmente o mapa. Guelke (apud GIRARDI, 2000) revela que, paradoxalmente, o desenvolvimento da tecnologia de mapeamento teria gerado uma separação perigosa entre Geografia e Cartografia e muitos geógrafos teriam parado de perceber os mapas e seus usos como ferramenta vital no entendimento geográfico, e passaram a usar o mapa apenas como uma ilustração, muitas vezes presente apenas para legitimar a natureza geográfica da obra. Importante destacar que, na Geografia, representação e localização são atributos indissociáveis (NOGUEIRA, 2009), tendo no mapa o seu meio mais expressivo, apesar de não único.

Ao trazer localização-descrição-representação como uma tríade, esse artigo pretendeu demonstrar que elas não poderiam ser vistas de modo independentes nas pesquisas geográficas, isto é, as três se uniriam na produção de conhecimento, não importando, nesse contexto, as diferenças de status e de objetivos gerais. Sendo a localização, vista a partir de uma concepção de espaço absoluto ou relativo-relacional, a descrição vista como fim ou como 
meio, ou a representação vista como produto ou processo, e suas possíveis diferentes combinações, o objetivo foi justificar a dificuldade metodológica que a pesquisa de doutoramento apresentou. Em outras palavras, o embaraço trazido pela necessidade de anonimato dos informantes, minou a capacidade da pesquisa em localizar-descreverrepresentar o objeto de estudo, colocando em risco a própria investigação dentro da Geografia.

\section{CONSIDERAÇÕES FINAIS}

O artigo partiu de um impasse metodológico surgido no decorrer da pesquisa de tese de doutoramento para a busca de suas razões na história do pensamento geográfico, em uma tentativa de associar o problema com a própria ontologia da Geografia. A tríade localizaçãodescrição-representação representou, para nós, a explicação da dificuldade de anonimato na geografia, como esse se associa diretamente a um espaço geográfico específico.

$\mathrm{Na}$ tentativa de respeitar as importantes questões éticas que apareceram na pesquisa, tentouse evitar, ao máximo, o uso de quaisquer elementos da tríade. No trabalho final, a localização foi omitida, as descrições foram realizadas de modo mais superficial, e a representação gráfica em formato de mapa foi substituída por um croqui, enquanto fotos foram tomadas de um modo que não se identificavam elementos conhecidos. Desse modo, era possível não usar coordenadas geográficas e apagar objetos espaciais que ajudariam na identificação da favela:

Figura 1 - Croqui da comunidade 1 e sua associação de moradores.

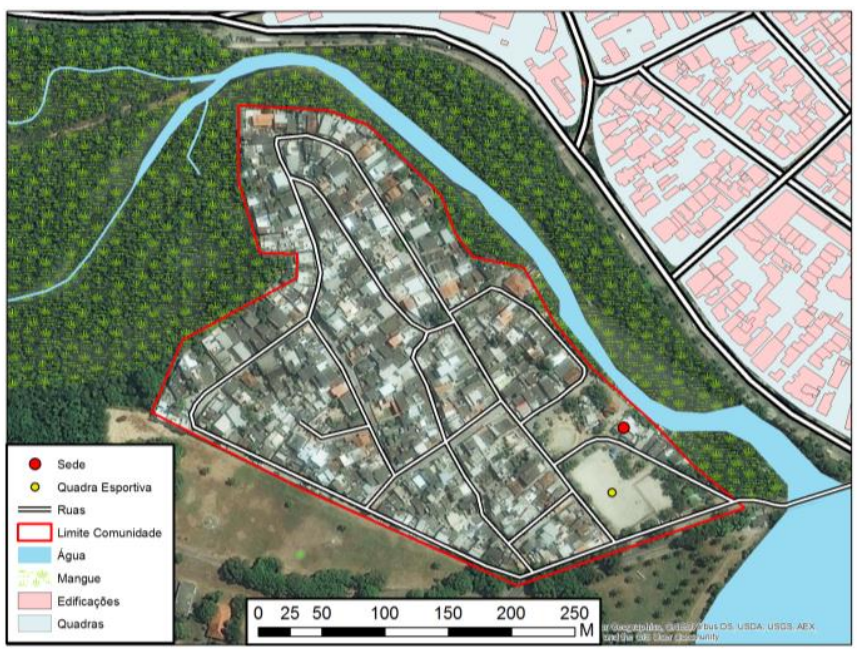

Fonte - Azevedo, 2016.

Porém, na defesa da tese, tal tentativa de solução não foi tão bem-sucedida. Um membro da banca, especialista na cidade do Rio de Janeiro, afirmou que, mesmo omitindo os nomes, ele teria conseguido identificar quais favelas a pesquisa se referia. Apesar de os trabalhos do mundo acadêmico muitas vezes não terem divulgação em grandes partes da sociedade, a apreensão maior era a respeito das consequências geradas se os informantes das duas favelas se reconhecessem e/ou fossem reconhecidos. Além de uma questão objetiva de segurança, a promessa de anonimato e, consequentemente, os deveres éticos da pesquisa estavam, pois, em xeque.

Outro membro da banca, apesar de afirmar que não teria reconhecido as favelas estudadas, declarou que teria sentido falta da localização, da descrição e da representação espaciais. Como a geografia tradicionalmente já afirma, os lugares, disse o membro, não seriam desconectados do mundo, assim, saber exatamente o onde da pesquisa o ajudaria a compreender o fenômeno e, consequentemente, avaliar o trabalho. Apesar de criticar o anonimato espacial trazido pela pesquisa, o membro disse não saber como sair desse imbróglio metodológico e, sugeriu, ao final, que talvez tivesse sido melhor que as partes mais tensas fossem omitidas ao longo do trabalho. Entretanto, o dilema era exatamente esse: ao retirar certas informações - não apenas as mais tensas, mas todas aquelas que os informantes disseram em sigilo - a caracterização das associações de moradores se perderia e não seria possível a diferenciação dos objetos estudados e a reflexão teórico-empírica estaria completamente avariada.

Por outro lado, a crítica anterior serviu para a reflexão aqui apresentada, pois o mapa na pesquisa de tese desenvolvida não seria apenas um mapa-ilustração, mas sim poderia ser 
objeto de análise de um leitor atento, a partir do momento em que a representação configuraria uma localização especifica e princípios de conexão (assim como defendido por Brunhes) poderiam ser ativados. Ao ler uma imagem, como foi apresentado, criamos as nossas próprias narrativas e novas interpretações podem ser geradas. Em outras palavras, é evidente, para um geógrafo, que uma favela na Baixada Fluminense é diferente de uma favela na Zona Sul carioca, consequentemente, suas associações de moradores poderiam ser interpretadas a partir dessa diferença espacial.

Por fim, o artigo buscou mostrar que os chamados "inconvenientes da pesquisa" podem também ser objetos de análise, a partir do momento em que refletem questões ontológicas da própria ciência. Sem dúvida, esse inconveniente apresentado é uma amostra das especificidades da Geografia e, sem a pretensão de dar uma resposta final para essa reflexão, cabe ao geógrafo buscar soluções para esse impasse metodológico. A tentativa produzida na tese de doutoramento foi apenas uma, certamente não a única e, visivelmente, talvez, não a melhor.

\section{REFERÊNCIAS BIBLIOGRÁFICAS}

AGNEW, J. MUSCARÀ, L. Making Political Geography. Plymouth: Rowman e Littlefield Publishers, 2012.

AMORIM FILHO, O. B. A evolução do pensamento geográfico e a fenomenologia. Revista Sociedade e Natureza, v.11, n.21/22, p.67-87, jan/dez 1999.

AVRITZER, L. O Novo associativismo. Lua Nova, n.39, p.149-174, 1997. https://doi.org/10.1590/S0102-64451997000100009

AZEVEDO, D. A. A democracia participativa como um sofisma: uma interpretação geográfica da democracia. Tese de doutorado: PPGG, UFRJ, 2016, 306p.

O papel da geografia no debate sobre o meio ambiente: superando dicotomias. Geouerj, v.1, p.456-473, 2017.

Modelos de democracia e espaços políticos: o caso da democracia participativa. Revista Geografares, n.26, v.1, p.126-146, 2018a. https://doi.org/10.7147/GEO26.21002

Os limites da democracia participativa: uma análise a partir dos Conselhos Municipais do Rio de Janeiro. Revista GEOgraphia, v.20, p.54-70, $2018 \mathrm{~b}$. https://doi.org/10.22409/GEOgraphia2018.v20i43.a27211

BACA, V. G. Teorias Geopoliticas. Revista de Investigaciones de la Fac. De Ciencias Administrativas. UNMSM, vol.8, n.15, Lima, p.19-23, Julio de 2015.

BALLESTEROS, A. G. Vidal de la Blache en la crítica al neopositivismo en la Geografía. Anales de Geografía de La Universidad Complutense. n.3. Ed. Univ. Complutense, p. 25-39, 1983.

BASSIN, M. Friedrich Ratzel (1844-1904). Geographers. Biobibliographical Studies, v.11, p.123-132, 1987.

BAULIG, H. A Geografia é uma Ciência? In.: CHRISTOFOLETTI, A. (Coord.). Perspectivas da Geografia. São Paulo: Difel, p. 59-70, 1982.

BERDOULAY, Vincent. A Escola Francesa de Geografia. São Paulo: Perspectiva, 2017 [1981].

BESSA, K. Diferenciação espacial como elemento próprio à natureza da geografia. Revista Mercator, vol. 9, numero 20, p.43-56, set/dez 2010. https://doi.org/10.4215/RM2010.0920.0003

BLACKSELL, M. Political Geography. New York: Routledge, 2010.

BRUNHES, J. Geografia humana. Rio de Janeiro: Editora Fundo de Cultura, 1962.

CAMARGO, J. C. G.; ELESBÃO, I. O problema do método nas ciências humanas: o caso da Geografia. Revista Mercator, a.3, n.4, p.7-18, 2004.

CAPEL, H. Institucionalización de la geografía y estrategias de la comunidad científica de los geógrafos. Geo Crítica, ํㅡㅇ-9, Universidad de Barcelona, p. 1-58, 1977.

CASTRO, I. E. Espaço Político. GEOgraphia, v.20, n.42, p.120-126, 2018.

CARLOS, A.F.A. Espaço-Tempo na Metrópole. São Paulo: Contexto, 2001. https://doi.org/10.22409/geographia.v20i42.1281 
CASTILLO, C. J. M. Jean Brunhes: a atualidade de um geógrafo do início do século XX. Revista Movimentos sociais e dinâmicas espaciais. Recife, vol.6, n.1, p.253-272, 2017.

CLAVAL, P. Epistemologia da geografia. Florianópolis: Editora UFSC, 2014.

CORRÊA, R. L. O Espaço geográfico: algumas considerações. In: SANTOS, M. (Coord.) Novos Rumos da Geografia Brasileira, Hucitec, 1982, p.25-34.

Espaço: um conceito-chave da Geografia. In: CASTRO, I. E; GOMES, P. C. C.; CORREA, R. L. (Coords.). Geografia: Conceitos e Temas. Rio de Janeiro: Bertrand Brasil, 1995, p.16-51.

. Trajetórias Geográficas. Rio de Janeiro: Bertrand Brasil, 2010.

COSCIONI, F. J. Richard Hartshorne: trajetória e obra. Terra Brasilis, n.9, p.1-15, 2017. https://doi.org/10.4000/terrabrasilis.2332

COSGROVE, D. E. Geography and Vision: Seeing, Imagining and Representing the World. Londres: i. b. Tauris. 2008.

DARDEL, E. O homem e a terra. São Paulo: Perspectiva, 2011 [1952].

DARVY, H. C. The problem of geographical description. Transactions and papers (Institute of British Geographers), n. 30, p.1-14, 1962. https://doi.org/10.2307/621298

DAVIS, W. M. The systematic description of land forms. Geographical Journal, n. 34, p.300326, 1909. https://doi.org/10.2307/1777147

. The principles of geographical description. Annals of the Association of American Geographers, n. 5, p.61-105, 1915. https://doi.org/10.1080/00045601509357038

DON, K. Sex, gender and culture among Brazilian transgendered prostitutes. Chicago: Chicago Press Books, 1998.

FLINT, C.; TAYLOR, P. Political Geography: world-economy, nation-state and locality. London: Prentice Hall, 2011 [1985].

FREMONT, A. Região um espaço vivido. Lisboa: Almedina, 1980.

GAMBARATO, R. R. Signo, significação, representação: um percurso semiótico. Revista Communicare, vol. 5, n. 2, p.45-54, 2005.

GIL, A. C. Métodos e técnicas de pesquisa social. 5. ed. São Paulo: Atlas, 1999.

GIL FILHO, S. F. Geografia cultural: estrutura e primado das representações. Espaço e Cultura, n.19-20, p.51-59, jan/dez 2005.

GIRARDI, G. Leitura de mitos em mapas: um caminho para repensar as relações entre geografia e cartografia. Revista Geografares, v. 1, $n^{0}$ 1, p.41-50, jun. 2000. https://doi.org/10.7147/GEO1.1162

GOMES, P. C. C. O conceito de região e sua discussão. In: CASTRO, I. E.; GOMES, P. C.C.; CORRÊA, R. L. (Coord.). Geografia: Conceitos e Temas. Rio de Janeiro: Bertrand Brasil, 1995, p.32-52. https://doi.org/10.15446/rcdg.v27n2.65165

Geografia e Modernidade. Rio de Janeiro: Bertrand Brasil, 1996.

Geografia Fin-De-Siécle: o discurso sobre a ordem espacial do mundo e o fim das ilusões. In: CASTRO, I. E.; GOMES, P. C. C; CÔRREA, R. L (Coord.). Explorações Geográficas. Rio de Janeiro: Bertrand Brasil, 1997, p.15-41.

A Condição Urbana. Rio de Janeiro: Bertrand Brasil, 2006.

O lugar do olhar: elementos para uma geografia da visibilidade. Rio de Janeiro: Bertrand Brasil, 2013.

GOMES, P.C.C; BERDOUALEY, V. Imagens da geografia: importância da dimensão visual no pensamento geográfico. Cuadernos de Geografía: Revista Colombiana de Geografía, vol.27, n.2, dic.2018, p.356-371, 2018.

HARTSHORNE, R. The Nature of Geography. Annals of the Association of American Geographers, v. 29, No. 3-4, Lancaster, 1939. https://doi.org/10.2307/2561166

HARVEY, D. Social justice and the city. Cambridge, 1977. 
HETTNER, A. A geografia como ciência corológica da superfície terrestre. Nossos Clássicos, $\begin{array}{lll}\text { GEOgraphia, } \quad \text { v.13, } & \text { p.136-152, 2011a } \\ \text { [1927]. }\end{array}$ https://doi.org/10.22409/GEOgraphia2011.v13i25.a13619

HETTNER, A. A essência e as tarefas da Geografia. Nossos Clássicos, GEOgraphia, v.13, n.26, p.136-149, 2011b [1927]. https://doi.org/10.22409/GEOgraphia2011.v13i26.a13628

HOLZER, W. O conceito de lugar na geografia cultural-humanista: uma contribuição para a geografia contemporânea. Regista GEOgraphia, Ano V, n.10, p.113-123, 2003.

A geografia humanista: Sua trajetória 1950-1990. Londrina: Eduel, 2016.

JAMMER, M. Conceitos de espaço: a história das teorias do espaço na física. Rio de Janeiro: Editora PUC Rio, 2010.

KOZEL, S. Das imagens às linguagens do geográfico: Curitiba, a capital ecológica. Tese (Doutorado em Geografia) - São Paulo: Universidade de São Paulo, 2001.

Comunicando e representando: mapas como construções socioculturais. In: SEEMAN, J. (Coord.). A aventura cartográfica: perspectivas, pesquisas e reflexões sobre a cartografia humana. Fortaleza: Expressão gráfica e editora, 2005, p.122-139.

LACOSTE, Y. A geografia - isso serve, em primeiro lugar, para fazer a guerra. Campinas: Papirus, 1988.

LEFEBVRE, H. The production of Space. Cambridge, 1999 [1970].

LIVINGSTONE, D. The Geographical Tradition. Malden/Oxford: Blackwell Publishing, 2008[1992].

LÓPEZ, M. V.; SÁNCHEZ, H. A.; PÉREZ, C. G. Fricción de la distancia, autocorrelación espacial de la productividad e impacto de la longitud por carretera en la dinámica de convergencia de la región centro de Mexico (1993-2003). Investigaciones Geograficas, Boletín del Instituto de Geografía, UNAM, n.71, p.72-87, 2010.

MORAIS, A. C. R. Geografia Pequena Histórica Crítica. São Paulo: HUCITEC, 1985.

MOREIRA. R. Para onde vai o pensamento geográfico? Por uma epistemologia crítica. São Paulo: Editora Contexto, 2006.

O que é a geografia? São Paulo: Editora brasiliense, 2010.

NOGUEIRA, R. E. Cartografia: representação, comunicação e visualização de dados espaciais. Florianópolis: Editora UFSC, 2009.

NUNES, E. O. Gramática política do Brasil: clientelismo, corporativismo e insulamento burocrático, Rio de Janeiro: Zahar Editor, 2010.

PAINTER, J.; JEFFREY, A. Political Geography. Washington D.C.: SAGE, 2009.

QUAINI, M. Marxismo e Geografia. Rio de Janeiro: Paz e Terra, 1979.

RIBEIRO, G. Interrogando a ciência: a concepção vidaliana da geografia. Confins: Revista Franco-brasileira de Geografia, n.8, p.1-15, 2010. https://doi.org/10.5433/1679$\underline{0359.2010 \mathrm{v} 31 \mathrm{n} 3 \mathrm{p} 793}$

ROSE, G. Visual methodologies. 2. ed. London: Sage, 2007.

ROSENDAHL, Z. Geografia e religião: uma proposta. Espaço e Cultura, Rio de Janeiro: Eduerj, 1995.

ROSS, J. L. S. Ecogeografia do Brasil: subsídios para planejamento ambiental. São Paulo: Oficiana de Textos, 2009.

SAHR, W.D.; ARANTES, L. A profusão das teorias espaciais e a fusão do espaço geográfico: Alfred Hettner e o projeto corológico. GEOgraphia, v.13, n.25, p.106-135, 2011. https://doi.org/10.22409/GEOgraphia2011.v13i25.a13618

SANGUIN, A.L. Geografia Política. Barcelona, Oikos-Tau, 1981.

SANTOS, M. A Natureza do Espaço: técnica e tempo, razão e emoção. São Paulo: Hucitec, 1997.

O trabalho do geógrafo no terceiro mundo. São Paulo: edusp, 2010 [1971].

SCHULTEN, S. The Geographical Imagination in America (1880-1950). Chicago, University of Chicago Press, 2001. 
SECOR, A. J. Social surveys, interviews, and focus group. In: GOMEZ, B.; JONES III, J. P (ed.). Research Methods in Geography: a critical introduction. Oxford: Wiley-Blackwell Editor, 2010, p.194-206.

SEEMAN, J. Arte, conhecimento geográfico e leitura de imagens: o geógrafo de Verner. Revista Pró Posições, Campinas, v. 20, n. 3 (60), p. 43-60, set./dez. 2009. https://doi.org/10.1590/S0103-73072009000300004

Friedrich Ratzel entre tradições e traduções: uma breve abordagem contextual. Terra Brasilis, n1, p.1-17, 2012.

SMITH, D. M. The politics and ethics of research. In: GOMEZ, B. JONES, J. P. Research methods in geography. Oxford: Wiley- blackwell Editors, 2010, p.411-423.

SOARES, M. T. S. Movimentos sociais urbanos: as associações de moradores de favelas no município do Rio de Janeiro. Revista Brasileira de Geografia, v.51, n.4, out./dez.,p.97-108, 1989.

SOJA, E. W. Geografias Pós-modernas. Rio de Janeiro: Jorge Zahar Editor, 1993.

SORRE, M. O Espaço do geógrafo e do sociólogo. In: SORRE, M (Org.). Geografia. São Paulo: Ática, 1984, p.140-155.

SOUZA, M. L. A Expulsão do Paraíso. O paradigma da complexidade e o desenvolvimento sócio-espacial. In: Castro, I. E.; GOMES, P. C. C.; CORRÊA, R. L. Explorações Geográficas. Rio de Janeiro: Bertrand Brasil, 1997, p.43-80.

Consiliência ou bipolarização epistemológica? Sobre o persistente fosso entre as ciências da natureza e as da sociedade - e o papel do geógrafo. In: SPOSITO, E. S.; SILVA, C. A.; NETO, J. L. S.; MELAZZO, E. S. A diversidade da geografia brasileira: escalas e dimensões da análise e da ação. Rio de Janeiro: Consequência, 2016, p. 13-56.

SOUZA, M. M. O. O trabalho de campo em geografia: por uma perspectiva participante de investigação científica. In: MARAFON, G. J.; RAMIRES, J. C.L.; RIBEIRO, M. A.; PESSÔA, V. L. S. (Coord.). Pesquisa qualitativa em geografia: reflexões teórico-conceituais e aplicadas. Rio de Janeiro, Eduerj, 2013, p.173-190.

SPRADLEY, J. Participant observation. New York: Holt, Rinehart and Winston, 1980.

SUERTEGARAY, D. M. A. Debate Contemporâneo: geografias ou geografia? Fragmentação ou totalização? GEOgraphia, vol.19, n.40, p.95-102, mai/ago 2017. https://doi.org/10.22409/GEOgraphia2017.v19i41.a13815

TUAN, Y-F. Topofilia: um estudo da percepção, atitudes e valores do meio ambiente. São Paulo: DIFEL, 1980.

VESENTINI, J. W. Repensando a geografia política. Um breve histórico crítico e a revisão de uma polêmica atual. Revista do Departamento de Geografia, n. 20, p.127-142, 2010. https://doi.org/10.7154/RDG.2010.0020.0009

WALLERSTEIN, I. O capitalismo histórico. São Paulo: Editora Brasiliense, 1985.

WHYTE, W. F. Sociedades de esquina. Rio de Janeiro: Jorge Zahar Editor, 2008 [1951].

Recebido em: 06/09/2018

Aceito para publicação em: 22/11/2018 